\title{
CZY SKARGA NADZWYCZAJNA DO SĄDU NADZWYCZAJNEGO SPELNILA SWOJE CELE?
}

\begin{abstract}
Streszczenie. Skarga nadzwyczajna jest nowym instrumentem procesowym, który funkcjonuje w polskim systemie prawnym od 3 kwietnia 2018 r. Już na etapie dyskusji nad nowelizacją ustawy o Sądzie Najwyższym, w której znalazły się przepisy, także dotyczące skargi nadzwyczajnej, wywoływała ona skrajne emocje. Mimo dwóch lat funkcjonowania nie jest jednoznacznie oceniana ani przez przedstawicieli doktryny, ani praktyków. Publikacja poświęcona jest wyłącznie aspektom proceduralnym, problemom związanym $\mathrm{z}$ wniesieniem skargi. Autorka stara się odpowiedzieć na pytanie, czy z tego punktu widzenia skarga spełnia wskazaną jej funkcję. Słuszny wydaje się postulat, by ustawowo ograniczyć jej stosowanie do bardzo wąskiej kategorii spraw, w których orzeczenie naruszyło słuszne interesy jednostek, a ewentualna korekta orzeczenia nie doprowadzi do naruszenia praw innych osób. Konieczne wydaje się także doprecyzowanie przesłanek wniesienia skargi, które, jak zostało wykazane, mają charakter nieprecyzyjny, oceny.
\end{abstract}

Słowa kluczowe: prawa i wolności człowieka, władza sądownicza, skarga nadzwyczajna, Sąd Najwyższy, prawo do sądu.

\section{DID THE EXTRAORDINARY APPEAL TO THE EXTRAORDINARY COURT FULFILL ITS OBJECTIVES?}

\begin{abstract}
An extraordinary appeal is a new procedural instrument that has been in operation in the Polish legal system since April 3, 2018. Already at the stage of discussions on the amendment to the Act on the Supreme Court, which also included provisions on the extraordinary appeal, it caused extreme emotions. Despite two years of operation, it is not unequivocally assessed by representatives of the doctrine or practitioners. The publication is devoted exclusively to procedural aspects, problems related to the lodging of a complaint. The author tries to answer the question whether, from this point of view, the complaint fulfills the indicated function. The postulate that its application should be statutorily limited to a very narrow category of cases in which the ruling violated the legitimate interests of individuals, and the possible correction of the ruling will not lead to violation of the rights of other people, seems right. It is necessary to specify the conditions for lodging a complaint, which has been shown to be imprecise and of assessment.
\end{abstract}

Keywords: human rights and freedoms, judiciary, extraordinary complaint, Supreme Court, right to a court.

* Uniwersytet Łódzki, Wydział Prawa i Administracji, Katedra Prawa Konstytucyjnego, adomanska@wpia.uni.lodz.pl. 
Skarga nadzwyczajna jest nowym instrumentem procesowym, który funkcjonuje w polskim systemie prawnym od 3 kwietnia 2018 r. ${ }^{1}$ Już na etapie dyskusji nad nowelizacją ustawy o Sądzie Najwyższym, w której znalazły się także przepisy dotyczące skargi nadzwyczajnej, wywoływała ona skrajne emocje. Mimo dwóch lat funkcjonowania nie jest jednoznacznie oceniana ani przez przedstawicieli doktryny, ani praktyków.

W uzasadnieniu do projektu ustawy wprowadzającej skargę nadzwyczajną wskazano, że jej zadaniem jest korygowanie prawomocnych orzeczeń sądowych. Proponowane rozwiązania miały przede wszystkim zapewnić realizację zasady sprawiedliwości społecznej oraz transparentność działalności Sądu Najwyższego (Szczucki 2018, 458).

Jej rozpatrywanie należy do właściwości Izby Kontroli Nadzwyczajnej i Spraw Publicznych, a w rozpoznawaniu skarg nadzwyczajnych uczestniczą ławnicy Sądu Najwyższego.

Ze względu na wielość wątków związanych z wprowadzeniem i obowiązywaniem analizowanej instytucji niniejsza publikacja poświęcona jest wyłącznie aspektom proceduralnym, przesłankom wniesienia skargi nadzwyczajnej. Autorka stara się odpowiedzieć na pytanie, czy z tego punktu widzenia skarga spełnia wskazaną jej funkcję.

\section{PRZESŁANKI WPROWADZENIA INSTYTUCJI SKARGI NADZWYCZAJNEJ DO POLSKIEGO SYSTEMU PRAWNEGO}

W uzasadnieniu do projektu ustawy o Sądzie Najwyższym czytamy, że skarga nadzwyczajna jest niejako odpowiedzią na zarzut sformułowany przez Trybunał Konstytucyjny, a dotyczący braku w polskim systemie prawnym odpowiedniego nadzwyczajnego środka zaskarżenia, który pozwoliłby na skuteczną ochronę praw i wolności gwarantowanych w Konstytucji RP². Jak wskazują wnioskodawcy w ocenie Trybunału

roli takiego szczególnego instrumentu nie spełnia skarga konstytucyjna, która została ukształtowana wąsko i jest nakierowana wyłącznie na usunięcie z porządku prawnego przepisu naruszającego prawa i wolności, nie zaś na skorygowanie wadliwości wynikającej z błędnego stosowania prawa i to także w sytuacji, kiedy miałoby ono charakter ewidentny i byłoby dostrzeżone przez instytucje szeroko rozumianego wymiaru sprawiedliwości. Inna konstrukcja skargi konstytucyjnej występująca w niektórych systemach prawnych (zwłaszcza niemieckim, austriackim czy hiszpańskim) stanowiłaby skuteczny instrument prawny zapobiegający utrzymywaniu się w porządku prawnym stanu nieusuwalnego naruszenia praw i wolności konstytucyjnych. Model

${ }^{1}$ Ustawa z dnia 8 grudnia 2017 r. o Sądzie Najwyższym, t.j. Dz. U. z 2019 r., poz. 825; z 2020 r., poz. 190.

${ }^{2}$ Wyrok Trybunału Konstytucyjnego z 19 lutego 2003 r., sygn. akt P 11/02 oraz postanowienie Trybunału Konstytucyjnego z 12 marca 2003 r., sygn. akt. S 1/03. 
polski został, jednakże podporządkowany założeniu wyraźnego rozróżnienia sfery kontroli konstytucyjności prawa i sfery kontroli poprawności jego stosowania ${ }^{3}$.

Powołując się na krytyczne stanowisko Trybunału Konstytucyjnego, ustawodawca uznał za wskazane wprowadzenie nowego, nadzwyczajnego środka zaskarżenia - skargi nadzwyczajnej. W uzasadnieniu do prezydenckiego projektu ustawy o Sądzie Najwyższym podkreślono, że nadzwyczajne środki zaskarżenia są „niewystarczające do ochrony konstytucyjnych wolności i praw obywateli, w przypadku ich naruszenia wyrokami sądów”, ze względu na fakt, że „w obrocie prawnym pojawiają się prawomocne orzeczenia, którym daleko do oczekiwanych standardów"4.

Inaczej tę kwestię ocenili przedstawiciele doktryny ${ }^{5}$. W jednej z opinii czytamy, że „funkcjonujący w procesie cywilnym oraz w procesie karnym system nadzwyczajnych środków zaskarżenia jest kompletny i wraz ze skargą konstytucyjną zapewnia gwarancję przestrzegania zasad konstytucyjnych oraz wolności i praw człowieka i obywatela. W tym zakresie brak jest uzasadnienia dla tworzenia kolejnej instytucji, która de facto powiela istniejące już nadzwyczajne środki zaskarżenia umożliwiające wzruszenie prawomocnego orzeczenia".

Podobne stanowisko prezentowali przedstawiciele doktryny. Zdaniem K. Piaseckiego wszystkie ustanowione przez ustawodawcę środki zaskarżenia tworzą spójny i komplementarny system, którego osnową jest m.in. zasada wyłączności (Piasecki red. 2016). Mimo krytycznej oceny projektu, ustawa o Sądzie Najwyższym, w której zawarte zostały przepisy dotyczące skargi nadzwyczajnej, została uchwalona 8 grudnia 2018 r. $^{7}$

\section{PRZESŁANKI WNIESIENIA SKARGI}

Szczegółowe przesłanki wniesienia skargi zostały wskazane w art. art. 89 ustawy o Sądzie Najwyższym ${ }^{8}$. W doktrynie zaprezentowano ich podział na przesłanki łączne i rozłączne. Do pierwszej grupy zaliczono: 1) możliwość wywiedzenia

\footnotetext{
${ }^{3}$ Wyrok Trybunału Konstytucyjnego z 19 lutego 2003 r., sygn. akt P 11/02.

${ }^{4}$ Uzasadnienie projektu ustawy z 8 grudnia 2017 r. o Sądzie Najwyższym, druk sejmowy VIII kadencji nr 2003.

${ }^{5}$ Opinia prawna w sprawie konstytucyjności prezydenckiego projektu ustawy o sądzie najwyższym, opinia zewnętrzna sporządzona przez dr. hab. Marcina Matczaka, UW, druk sejmowy VIII kadencji nr 2003.

${ }^{6}$ Opinia Ośrodka Badań, Studiów i Legislacji Krajowej Rady Radców Prawnych w przedmiocie skargi nadzwyczajnej przewidzianej w prezydenckim projekcie ustawy o Sądzie Najwyższym Ośrodek Badań, Studiów i Legislacji Krajowej Rady Radców Prawnych Warszawa, dnia 12 listopada $2017 \mathrm{r}$.

${ }^{7}$ T.j. Dz. U. z 2019 r., poz. 825; z 2020 r., poz. 190.

${ }^{8}$ Ustawa z dnia 8 grudnia 2017 r. o Sądzie Najwyższym.
} 
skargi nadzwyczajnej jedynie od orzeczeń prawomocnych sądów powszechnych oraz wojskowych kończących postępowanie w sprawie, 2) konieczność wniesienia omawianego środka zaskarżenia dla zapewnienia zgodności z zasadą demokratycznego państwa prawnego urzeczywistniającego zasady sprawiedliwości społecznej, 3) brak możliwości uchylenia lub zmiany kwestionowanego orzeczenia w trybie innych niż skarga nadzwyczajnych środków zaskarżenia. Oznacza to, że muszą one wystąpić łącznie w danym przypadku, by skarga nadzwyczajna była dopuszczalna i mogła zostać merytorycznie rozpoznana (Bagińska 2018, 288).

Wąsko został określony także zakres przedmiotowy skargi, czyli przesłanki rozłączne. Cechą charakterystyczną przesłanek rozłącznych jest to, że każda z nich konkretyzuje, jakiego typu naruszenie może miejsce w danym przypadku. Mogą to być: 1) naruszenie zasad lub wolności i praw człowieka i obywatela określonych w Konstytucji, 2) rażące naruszenie prawa przez błędną jego wykładnię lub niewłaściwe zastosowanie, 3) oczywista sprzeczność istotnych ustaleń sądu $\mathrm{z}$ treścią zebranego $\mathrm{w}$ sprawie materiału dowodowego.

\subsection{Przesłanki lączne}

Skarga nadzwyczajna zgodnie z art. 89 §1 ustawy o SN przysługuje od orzeczeń prawomocnych, które kończą postępowanie w sprawie. Oznacza to, że z zakresu skargi wyłączone zostały orzeczenia sądów powszechnych czy wojskowych, które nie kończą postępowania oraz orzeczenia sądów administracyjnych (Szczucki 2018, 470). Ponadto $§ 3$ i 4 art. 90 UoSN wskazują w jakich sprawach skarga jest niedopuszczalna. W następstwie, skargi nie można skutecznie wnieść od wyroku ustalającego nieistnienie małżeństwa, orzekającego unieważnienie małżeństwa albo rozwód, jeżeli choćby jedna ze stron po uprawomocnieniu się takiego orzeczenia zawarła związek małżeński, oraz od postanowienia o przysposobieniu, a także w sprawach o wykroczenia i wykroczenia skarbowe. Przywołany wyżej art. 90. u.o.s.n. wskazuje także, że od tego samego orzeczenia w interesie tej samej strony skarga nadzwyczajna może być wniesiona tylko raz i nie można oprzeć jej na zarzutach, które były przedmiotem rozpoznawania skargi kasacyjnej lub kasacji przyjętej do rozpoznania przez Sąd Najwyższy.

Rozważyć należy, czy wskazana w pkt.1 przesłanka wzmacnia, czy też podważa jedną z podstawowych zasad ustrojowych Rzeczypospolitej, mianowicie zasadę ochrony praw i wolności człowieka9 . Trybunał Konstytucyjny wielokrotnie podkreślał, że zasada ta sprzeciwia się takiemu ukształtowaniu systemu środków zaskarżenia, który nie pozwala na wyeliminowanie - w drodze precyzyjnie uregulowanych nadzwyczajnych środków zaskarżenia - orzeczeń, które stały się prawomocne, mimo że z powodu swej treści naruszają konstytucyjne wolności i prawa człowieka i obywatela ${ }^{10}$.

\footnotetext{
${ }^{9}$ Art. 5 Konstytucji RP z dnia 2 kwietnia 1997 r., Dz. U. z 1997 r., nr 78, poz. 483 ze zm.

${ }^{10}$ Postanowienie TK z 12 marca 2003 r., sygn. akt. S 1/03.
} 
Treść tej ostatniej z przywołanych zasad była wielokrotnie przedmiotem rozważań Trybunału Konstytucyjnego. Jest ona ważnym elementem prawa do sądu i ma istotne znaczenie z punktu widzenia realizacji konstytucyjnych zasad bezpieczeństwa prawnego i pewności prawa. $Z$ tych względów podstawowe znaczenie ma takie ukształtowanie postępowania sądowego, aby zapadło w nim wiążące rozstrzygnięcie zgodne z prawem i nie zachodziła konieczność wzruszania prawomocnego orzeczenia ${ }^{11}$. Trwałość orzeczeń sądowych zapewnia pewność i bezpieczeństwo prawne ${ }^{12}$. Musimy jednak mieć świadomość, że podobnie jak wiele innych zasad nie ma ona charakteru absolutnego. Wzruszenia prawomocnych orzeczeń sądowych w wyjątkowych i ściśle określonych sytuacjach może wymagać realizacja innych wartości i norm konstytucyjnych. Jednak odstępstwo od tej zasady powinno być motywowane potrzebą eliminacji z porządku prawnego orzeczeń prawomocnych, ale dotkniętych szczególnie poważnymi wadami ${ }^{13}$. Podważenie prawomocności musi każdorazowo być przedmiotem skrupulatnego ważenia wartości ${ }^{14}$. W doktrynie już na etapie prac nad ustawą podnoszono, że w związku z powyższym skarga nadzwyczajna pozostaje w sprzeczności z konstytucyjną zasadą stabilności orzeczeń sądowych, zasadą państwa prawnego, zasadą ochrony zaufania do państwa oraz prawa do rozstrzygania sprawy sądowej w rozsądnym czasie ${ }^{15}$.

Należy w związku z powyższym zauważyć, że skarga nadzwyczajna ingeruje w istotny sposób w zasadę stabilności orzeczeń. W wyroku z 1 kwietnia 2008 r. ${ }^{16}$ Trybunał Konstytucyjny stwierdził m.in., że prawo do sądu obejmuje prawo do uzyskania wiążącego rozstrzygnięcia, a więc rozstrzygnięcia, które w sposób definitywny rozstrzygnie określoną sprawę, będzie podlegać wykonaniu i poza wyjątkowymi sytuacjami nie będzie mogło zostać zmienione, a zasadniczym instrumentem korekty orzeczeń niezgodnych z prawem jest kontrola instancyjna sprawowana przez sąd drugiej instancji.

Podkreślenia wymaga fakt, że skoro ideą skargi nadzwyczajnej ma być eliminowanie z obrotu prawnego orzeczeń, które naruszają zasady określone w Konstytucji RP, to tak określona przesłanka, która jest niezwykle pojemna treściowo i zarazem ma nieostry charakter, nie tylko nie realizuje tego celu, ale godzi w opisaną wyżej zasadę stabilności orzeczeń. Może być w związku z tym

${ }^{11}$ Wyrok Trybunału Konstytucyjnego z 21 lipca 2009 r., sygn. akt K 7/09.

${ }_{12}$ Wyrok Trybunału Konstytucyjnego z 19 lutego 2003 r., sygn. akt P 11/02, OTK ZU nr 2/A/2003, poz. 12.

${ }^{13}$ Wyrok Trybunału Konstytucyjnego z 17 maja 2004 r., sygn. akt SK 32/03.

${ }^{14}$ Wyrok Trybunału Konstytucyjnego z 24 października 2007 r., sygn. akt SK 7/06, OTK ZU nr 9/N2007, poz. 108, s. 1364-1365.

${ }^{15}$ Opinia Ośrodka Badań, Studiów i Legislacji Krajowej Rady Radców Prawnych w przedmiocie skargi nadzwyczajnej przewidzianej w prezydenckim projekcie ustawy o Sądzie Najwyższym Ośrodek Badań, Studiów i Legislacji Krajowej Rady Radców Prawnych Warszawa, 12 listopada $2017 \mathrm{r}$.

${ }^{16}$ Wyrok z 1 kwietnia 2008 r., sygn. akt SK 77/06. 
wykorzystywana także dla celów politycznych, np. jako środek wzruszania orzeczeń sądów powszechnych w przedmiocie ważności wyborów do organów samorządu terytorialnego ${ }^{17}$.

Ponadto celem projektodawcy miało być stworzenie instytucji umożliwiającej przywrócenie elementarnego ładu prawnego zgodnego z zasadą sprawiedliwości społecznej, czemu służyć miała przede wszystkim realizacja drugiej z przesłanek łącznych. Zgodnie z wolą ustawodawcy skarga nadzwyczajna może być wniesiona od prawomocnego orzeczenia sądu powszechnego lub sądu wojskowego kończącego postępowanie w sprawie, jeżeli jest to konieczne dla zapewnienia zgodności z zasadą demokratycznego państwa prawnego urzeczywistniającego zasady sprawiedliwości społecznej. Oznacza to, że zaskarżeniu będą mogły podlegać tylko takie orzeczenia, które naruszać będą „klauzulę demokratycznego państwa prawnego i sprawiedliwości społecznej”, w powiązaniu ze szczegółowymi przesłankami wskazanymi w dalszej części artykułu 89 ustawy o Sądzie Najwyższym. Może to potencjalnie stanowić podstawę do poważanych wątpliwości interpretacyjnych w zakresie stosowania i wykładni omawianego artykułu.

Dyrektywa ta została także wskazana jako jedno z zadań wyznaczonych Sądowi Najwyższemu. Artykuł 1 ustawy wskazuje, że Sąd Najwyższy ma sprawować wymiar sprawiedliwości za pomocą „,kontroli nadzwyczajnej prawomocnych orzeczeń sądowych w celu zapewnienia ich zgodności z zasadą demokratycznego państwa prawnego urzeczywistniającego zasady sprawiedliwości społecznej przez rozpoznawanie skarg nadzwyczajnych". Należy przypomnieć, że klauzula demokratycznego państwa prawnego ma charakter dynamiczny. Trybunał Konstytucyjny wyprowadził z jej treści szereg zasad szczegółowych o charakterze dyrektywalnym, z których każda może stanowić samoistną podstawę oceny konstytucyjności aktu, a zasady składowe należy traktować autonomicznie ${ }^{18}$. Doprowadziło to do sformułowania w doktrynie zarzutu inflacji zasad i związanego $\mathrm{z}$ tym zatarcia ich znaczenia dla procesu interpretacji względem innych norm konstytucyjnych ${ }^{19}$.

Drugim z elementów koniecznych tej przesłanki, równie pojemnym treściowo i nieprecyzyjnym, są zasady sprawiedliwości społecznej. Podobnie jak klauzula demokratycznego państwa prawnego i ta jest kryterium niejasnym, posiadającym w swej treści wiele formuł (Domańska 2001). W literaturze spór wokół pojęcia sprawiedliwości społecznej ma charakter odwieczny. Powstało wiele teorii, a próbę zdefiniowania owej mglistej formuły podejmowali niemal wszyscy wielcy przedstawiciele nauki - począwszy od klasycznych filozofów prawa i polityki, po współczesnych przedstawicieli nauk prawnych, filozofii, etyki, ale także i polityki ${ }^{20}$.

${ }^{17}$ Art. 394 ustawy z dnia 5 stycznia 2011 r. Kodeks wyborczy, t.j. Dz. U. z 2020 r., poz. 1319.

${ }^{18}$ Orzeczenie Trybunału Konstytucyjnego z 4 grudnia 1990 r., K 12/90;, z 22 sierpnia 1990 r., k 7/90; z 23 czerwca 1997 r., sygn. akt K 3/97.

${ }^{19}$ Zob. m.in. Działocha 1997, 92.

${ }^{20}$ Szerzej por. Domańska 2001, 13-46. 
Stosunkowo najbardziej znana jest ogólna definicja sprawiedliwości Ulpiana, według którego jest to „stała i niezmienna wola przyznawania każdemu należnego mu prawa"21. Sprawiedliwość, zwłaszcza, społeczna, jest pojęciem o silnym zabarwieniu emocjonalnym, dlatego trudno ją jednoznacznie zdefiniować. Mimo ogromnej liczby teorii (Domańska 2001, 13-58) termin ten nadal nie jest dookreślony. Powiązanie przez ustrojodawcę sprawiedliwości społecznej z klauzulą demokratycznego państwa prawnego uczyniło z niej naczelną wartość prawa, kryterium oceny innych wartości - instytucji ustrojowych, systemów społecznych działań jednostkowych i grupowych (Tokarczyk 1997, 3), ale spowodowało także, że wartość ta stała się swego rodzaju elementem koniecznym, determinantem klauzuli demokratycznego państwa prawnego. Trybunał stwierdził także, że sprawiedliwość jest przeciwieństwem arbitralności, wymaga bowiem, aby zróżnicowanie poszczególnych ludzi pozostawało w odpowiedniej relacji do ich sytuacji ${ }^{22}$. To zasady sprawiedliwości społecznej wyznaczają treściowo koncepcję demokratycznego państwa prawnego. W tym sensie są one częścią ideału prawno-politycznego (Wróblewski 1990, 3 i n., 15). Już tak ogólnie przedstawione problemy związane z interpretacją zasad sprawiedliwości społecznej wskazują, że trudno jest uznać ją za precyzyjną przesłankę wniesienia skargi nadzwyczajnej.

Kolejne wątpliwości, wśród przedstawicieli doktryny, budzi treść sformułowań użytych w trzeciej z przesłanek łącznych, mianowicie ustawowej formule wyrażonej w art. 89. § 1: „orzeczenie nie może być uchylone lub zmienione w trybie innych nadzwyczajnych środków zaskarżenia”. Literalna wykładnia prowadzi do wniosku, że przesłanką skargi nadzwyczajnej warunkującą jej dopuszczalność jest jej subsydiarność. Rozważenia wymaga jednak charakter owej subsydiarności. Czy jest to środek subsydiarny względny czy bezwzględny, którego dopuszczalność uzależniona jest od wyczerpania możliwości skorzystania przez uprawnionego z innych nadzwyczajnych środków zaskarżenia orzeczenia. Zdaniem K. Szuckiego oznacza to, że organ badający możliwość wniesienia skargi nadzwyczajnej, przesłankę subsydiarności powinien oceniać na moment analizy wniosku (Szucki 2018, 472). Odpowiedzi na to pytanie udzielił także Sąd Najwyższy. W jego ocenie ,efektywna ochrona wynikająca z instytucji skargi nadzwyczajnej może realizować się jedynie przy przyjęciu założenia o względnie subsydiarnym charakterze tego nadzwyczajnego środka zaskarżenia"23. W innym orzeczeniu podkreślił, że omawiana skarga jest dopuszczalna, gdy nie ma w chwili jej wnoszenia możliwości uchylenia lub zmiany prawomocnego orzeczenia w trybie innych nadzwyczajnych środków zaskarżenia, a zatem skarga nadzwyczajna ustępuje innym zarówno zwyczajnym, jak i nadzwyczajnym środkom zaskarżenia,

${ }^{21}$ „Iustitia est constans et perpetua voluntas ius suum cuique tribuendi” - ,sprawiedliwość jest określoną stałą wolą rozdzielania każdemu tego, co mu się należy”, Corpus Iuris Civilis, Digestum Veteus (D.1. 1/1-2).

${ }^{22}$ Orzeczenie Trybunału Konstytucyjnego z 22 sierpnia 1990 r., sygn. akt K 7/90.

${ }^{23}$ Postanowienie Sądu Najwyższego z 24 lipca 2019 r., I NSNc 5/19. 
ma jednakże pierwszeństwo przed skargą o stwierdzenie niezgodności z prawem prawomocnego orzeczenia ${ }^{24}$.

W judykaturze podjęto także próbę ustalenia kolejności wnoszenia skargi nadzwyczajnej i skargi o stwierdzenie niezgodności z prawem prawomocnego orzeczenia. W postanowieniu z 30 sierpnia 2018 r. Sąd Najwyższy ${ }^{25}$ wskazał, że skoro przyczyny uwzględnienia skargi nadzwyczajnej są zbieżne z przyczynami uwzględnienia skargi o stwierdzenie niezgodności z prawem prawomocnego orzeczenia, a także biorąc pod uwagę unormowanie zawarte w art. $89 \S 4$ ustawy o Sądzie Najwyższym, należy przyjąć, iż począwszy od 4 kwietnia 2018 r. strona wnosząca skargę o stwierdzenie niezgodności z prawem prawomocnego orzeczenia, wypełniając obowiązek przewidziany w art. $424^{5} \S 1$ pkt 5 k.p.c., musi wykazać, że złożyła do uprawnionego organu wniosek o wniesienie skargi nadzwyczajnej i nie został on uwzględniony. Niewykazanie tej okoliczności powoduje odrzucenie skargi o stwierdzenie niezgodności z prawem prawomocnego orzeczenia na podstawie art. $424^{8} \S 1$ k.p.c. Zdaniem L. Bagińskiej jedynym ograniczeniem skutecznego wniesienia skargi nadzwyczajnej w kontekście wykorzystania przez skarżącego innych środków zaskarżenia jest możliwość zmiany lub uchylenia zaskarżonego orzeczenia w drodze innych środków nadzwyczajnych, co oznacza, że skarga nadzwyczajna będzie dopuszczalna wtedy, gdy skarżącemu nie przysługuje prawo do wniesienia skargi kasacyjnej lub innego nadzwyczajnego środka zaskarżenia, albo prawo takie przysługiwało, ale rozstrzygnięcie wydane na skutek wniesienia tego środka nie spowodowało zmiany lub uchylenia wadliwego orzeczenia w sposób eliminujący jego wadliwośćc ${ }^{26}$. Oznacza to zdaniem autorki, że potencjalna możliwość wywiedzenia np. skargi o wznowienie postępowania uniemożliwia wniesienie skargi nadzwyczajnej.

Zgodnie z treścią ustawy nie istnieje obowiązek, aby w niesienie skargi nadzwyczajnej poprzedzone miało być wniesieniem innego środka. W danej sprawie mogą nie występować przesłanki umożliwiające wcześniejsze wniesienia innego nadzwyczajnego środka zaskarżenia. Badając przesłanki wniesienia skargi nadzwyczajnej, należy sprawdzić, czy jest to jedyny możliwy obecnie do wniesienia środek zaskarżenia (Szucki 2018, 472).

Ponadto ustawodawca wskazał, że po wniesieniu kasacji czy skargi kasacyjnej od orzeczenia istnieje możliwość wniesienia skargi nadzwyczajnej, jeżeli nie doszło do uchylenia lub zmiany orzeczenia. Jednak w takim przypadku podstawą skargi nadzwyczajnej nie mogą być zarzuty, które stały się przedmiotem rozpoznania skargi kasacyjnej lub kasacji (art. 90 §), którą rozpoznawał Sąd Najwyższy. Oznacza to, że skarga może zostać oparta na zarzutach takich samych, jakie wystąpiły w kasacji lub skardze kasacyjnej w dwóch przypadkach: złożona

\footnotetext{
${ }^{24}$ Wyrok z 3 czerwca 2019 r., sygn. akt I NSNc 7/19, zob. Ereciński, Weitz 2019, 16.

${ }^{25}$ Postanowienie Sądu Najwyższego z 30 sierpnia 2018 r., III CNP 9/18.

${ }^{26}$ Zob. Bagińska 2018, 289-290; podobny pogląd prezentują zob. Ereciński, Weitz 2019, 15.
} 
kasacja czy skarga kasacyjna nie zostały przyjęte przez Sąd Najwyższy do rozpoznania lub w wypadku przyjęcia któregoś z tych środków, jednak zarzuty nie stały się przedmiotem rozpoznawania ${ }^{27}$.

\subsection{Przesłanki rozlączne}

Pierwsza z przesłanek szczególnych wskazuje, że skarżący musi wykazać, że orzeczenie narusza zasady lub wolności i prawa człowieka i obywatela określone w konstytucji. Należy zauważyć, że także ta przesłanka zawiera w swej treści pojęcia nieostre, nieprecyzyjne. O ile można przyporządkować daną normę do określonego prawa czy wolności człowieka i obywatela, o tyle pojęcie zasad nie jest jednoznacznie zdefiniowane ani w literaturze, ani orzecznictwie. Przykładem może być choćby zasada godności - źródła praw i wolności człowieka. Cechą charakterystyczną pojęcia zasad jest ich szeroki zakres, niektóre wyrażone są bezpośrednio w postanowieniach Konstytucji RP, inne wyprowadzane są przez orzecznictwo z treści przepisów (Domańska 2019, 19 i n.). Niemożliwe jest stworzenie jednolitego katalogu zasad. Ogromne znaczenie przy określaniu treści, ale także wyprowadzaniu nowych z już obowiązujących zasad miał Trybunał Konstytucyjny. Oparcie skargi na tak niejasnej podstawie może powodować oddalenie jej z uwagi na inne rozumienie treści przywołanej zasady.

Respektowanie praw człowieka uznawane jest za istotny warunek sprawiedliwego funkcjonowania ładu państwowego (Chmaj red. 2016, 14). Przyjąć należy, że wzorcem kontroli w tym postępowaniu może być tylko taka norma ustawy zasadniczej, która statuuje określoną wolność lub prawo podmiotowe. Stąd wydaje się, że zawężenie podstawy wniesienia skargi tylko do praw i wolności określonych w konstytucji, a pomijanych wiążących Polskę ratyfikowanych umów międzynarodowych statuujących owe normy jest rozwiązaniem błędnym. I choć przyporządkowanie danej normy do katalogu wolności i praw człowieka i obywatela jest procesem mniej skomplikowanym niż wskazanie zasad określonych w konstytucji, to nie oznacza to, że jest to czynność prosta.

Jednocześnie ustawodawca nałożył na Sąd Najwyższy obowiązek wystąpienia z pytaniem prawnym do Trybunału Konstytucyjnego, jeżeli przy rozpatrywaniu skargi nadzwyczajnej SN uzna, że przyczyną naruszenia przez orzeczenie zasad lub wolności i praw człowieka i obywatela, określonych w Konstytucji, jest niezgodność ustawy z Konstytucją (art. $91 \S 2$ zd. pierwsze ustawy o Sądzie Najwyższym). W doktrynie pojawiły się zdania krytyczne zarzucające takiemu rozwiązaniu, że jest to niezasadne ograniczenie bezpośredniego stosowania ustawy zasadniczej przez Sąd Najwyższy (Balcerzak 2018).

Ustawodawca nie nałożył natomiast na SN obowiązku wystąpienia z pytaniem prawnym do TK, jeżeli przy rozpatrywaniu skargi nadzwyczajnej SN uzna, że przyczyną naruszenia praw i wolności człowieka jest niezgodność normy

${ }^{27}$ Art. 90 ustawy o Sądzie Najwyższym. 
prawa $\mathrm{z}$ ratyfikowaną umową międzynarodową. W następstwie przyjąć należy, że Sąd Najwyższy władny jest ustalić, że norma prawna narusza prawa i wolności człowieka gwarantowane w EKPC bez obligatoryjnego zwracania się z pytaniem prawnym do Trybunału Konstytucyjnego. Ponieważ ratyfikowana umowa międzynarodowa stanowi część krajowego porządku prawnego i jest stosowana bezpośrednio (art. 91 ust. 1 Konstytucji), dlatego uważam, że SN może bezpośrednio stosować EKPC, gdy stwierdzi jej naruszenie (Balcerzak 2018).

Kolejną przesłanką rozłączną jest rażące naruszenie prawa. Konieczne jest przy tym wykazanie, że naruszenie prawa nastąpiło przez błędną jego wykładnię lub niewłaściwe zastosowanie. Nie ma wątpliwości, że pojęcie „rażące naruszenie prawa" ma charakter niedookreślony i ex definitione ocenny.

Oczywistość naruszenia prawa, w takim przypadku, polega na „oczywistej” sprzeczności pomiędzy treścią rozstrzygnięcia a przepisem prawa stanowiącym jego podstawę prawną (Adamczewski 2018). Przyjmuje się, że naruszenie prawa materialnego przez błędną wykładnię polega na błędnym ustaleniu treści pojęć prawnych, w tym zasad współżycia społecznego ${ }^{28}$. Naruszenie prawa materialnego przez niewłaściwe zastosowanie polega natomiast na błędnym przyjęciu lub zaprzeczeniu związku, jaki zachodzi między faktem ustalonym w procesie a normą prawną (Ereciński 2016). Polega ono na błędnym podciągnięciu konkretnego stanu faktycznego pod hipotezę normy prawnej ${ }^{29}$. Interpretując treść omawianej przesłanki, należy uznać, że chodzi tu zarówno o błędną wykładnie prawa procesowego, jak i złe zastosowanie prawa materialnego. Zarówno w jednym, jak i drugim przypadku dojść musi do rażącego naruszenia prawa.

Ostatnia z przesłanek rozłącznych wymienionych przez ustawodawcę, która warunkuje skuteczne wniesienie skargi nadzwyczajnej, wystąpi wówczas, gdy ustalenia faktyczne dokonywane przez sąd różnią się od materiału zebranego w postępowaniu. Przesłanka wskazana w art. $89 \S 1$ pkt 3 dotyczy ustaleń faktycznych, a Sąd Najwyższy ocenia dowody, które zostały zgromadzone zarówno w I, jak i II instancji. Pod uwagę nie mogą być brane dowody, które nie zostały przeprowadzone w toku sprawy. W sytuacji, gdy Sąd Najwyższy dostrzeże sprzeczność między ustaleniami faktycznymi a środkami dowodowymi, wówczas uwzględnia skargę nadzwyczajną. Przy czym owa sprzeczność musi mieć charakter istotny co do rozstrzygnięcia i musi dotyczyć „faktu głównego w procesie dowodzenia", czyli konkretnie zdarzeń, które są przedmiotem postępowania.

Powyższa przesłanka ma urzeczywistniać cel, dla którego instytucja skargi została wprowadzona do polskiego systemu prawnego, służy bowiem realizacji prawa do sądu i ma pomóc w naprawie błędów popełnianych przez wymiar sprawiedliwości.

${ }^{28}$ Wyroki Sądu Najwyższego z 8 marca 2012 r., III PK 52/11 oraz z 19 stycznia 1998 r., I CKN 424/97.

${ }^{29}$ Postanowienie Sądu Najwyższego z 20 listopada 2002 r., II CKN 1492/00; postanowienie Sądu Najwyższego z 20 czerwca 1997 r., II CKN 246/97; wyrok Sądu Najwyższego z 19 stycznia 1998 r., I CKN 424/97. 
Zgodnie z treścią art. 95 pkt 1 UoSN w zw. z art. 3984 § 1 pkt 2 k.p.c., skarga nadzwyczajna powinna zwierać nie tylko przytoczenie jej podstaw, ale i ich uzasadnienie. To właśnie w uzasadnieniu będą wykazane owe oczywiste sprzeczności istotnych ustaleń sądu z treścią zebranego w sprawie materiału dowodowego. Brak uzasadnienia podstawy skargi jest nieusuwalny i powinien prowadzić do odrzucenia skargi bez wzywania strony skarżącej do usunięcia braków ${ }^{30}$.

\section{PODSUMOWANIE}

Skarga nadzwyczajna jest instrumentem o nieprecyzyjnie określonym zakresie przedmiotowym i wąsko określonym zakresie podmiotowym. Może być ona wniesiona wyłącznie przez: Rzecznika Praw Obywatelskich, Prokuratora Generalnego, a także w zakresie swojej właściwości, Prezesa Prokuratorii Generalnej Rzeczypospolitej Polskiej, Rzecznika Praw Dziecka, Rzecznika Praw Pacjenta, Przewodniczącego Komisji Nadzoru Finansowego, Rzecznika Finansowego, Rzecznika Małych i Średnich Przedsiębiorców i Prezesa Urzędu Ochrony Konkurencji i Konsumentów (art. 89 § 2 UoSN). W odniesieniu do orzeczeń, które uprawomocniły się przed wejściem w życie ustawy o Sądzie Najwyższym (tj. przed 3 kwietnia 2018 r.), legitymacja do wniesienia skargi nadzwyczajnej przysługuje wyłącznie Rzecznikowi Praw Obywatelskich i Prokuratorowi Generalnemu (art. $115 \S 1$ 1a UoSN). Od tego samego orzeczenia w interesie tej samej strony skarga nadzwyczajna może być wniesiona tylko raz.

Przez czas obowiązywania analizowanych przepisów tylko do Rzecznika Praw Obywatelskich wpłynęła ogromna liczba wniosków obywateli o skorzystanie z takiej możliwości (do końca lutego 2020 r. było ich 6648, w tym 1904, głównie w sprawach cywilnych) ${ }^{31}$. Do Prokuratora Generalnego wpłynęło zaś ponad 3240 pism zawierających wniosek o skierowanie skargi nadzwyczajnej od prawomocnego orzeczenia sądowego kończącego postępowanie (w większości są to sprawy cywilne - spadkowe i rodzinne, niewiele jest spraw karnych) ${ }^{32}$. Jednocześnie obywatele zaczęli się skarżyć na wpływ nowej instytucji na realną możliwość skorzystania ze skargi o stwierdzenie niezgodności z prawem prawomocnego orzeczenia ${ }^{33}$. Jak wynika z danych statystycznych, duża część spraw, które wpłynęły do SN, dotyczy spraw cywilnych. Chodziło o przeróżne kwestie. Były to na przykład sprawy spadkowe, kilka skarg dotyczyło nakazów

\footnotetext{
${ }^{30}$ Postanowienie Sądu Najwyższego z 13 czerwca 2008 r., III CSK 104/08.

${ }^{31} \mathrm{https} / /$ www.rpo.gov.pl/pl/content/rpo-skarga-nadzwyczajna-ograniczyla-skargi-naniezgodnosc-z-prawem-prawomocnego-orzeczenia [dostęp: 20.09.2020].

32 https://www.rp.pl/Sedziowie-i-sady/302059932-Tysiace-wnioskow-ale-malo-skargnadzwyczajnych-do-Sadu-Najwyzszego.html [dostęp: 20.09.2020].

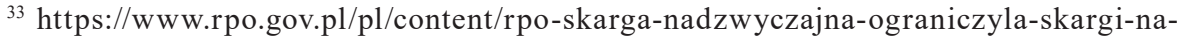
niezgodnosc-z-prawem-prawomocnego-orzeczenia [dostęp: 21.09.2020].
} 
zapłaty w postępowaniu upominawczym, spraw o zasiedzenie, o eksmisję czy też o uzgodnienie treści księgi wieczystej. Największym problem w ocenie SN stanowią braki formalne. $\mathrm{Z}$ tego powodu ponad połowa skarg wraca do sądów w celu uzupełnienia. Najczęściej chodzi o nienadanie prawidłowego biegu skardze poprzez np. niedoręczenie jej odpisów stronom postępowania, ale też np. brakowało uzasadnień zaskarżonych orzeczeń. Są skargi, które zwracano więcej niż raz ${ }^{34}$.

W doktrynie podnosi się także, że istnieją wątpliwości co do zgodności instytucji skargi nadzwyczajnej ze standardem Konstytucji RP oraz Europejskiej Konwencji o Ochronie Praw Człowieka i Podstawowych Wolności. Niektórzy postulują uchylenie przepisów o skardze nadzwyczajnej z ustawy o SN albo znowelizowanie jej w celu radykalnego ograniczenia przesłanek stosowania skargi nadzwyczajnej ${ }^{35}$. Słuszny wydaje się postulat, by ustawowo ograniczyć jej stosowanie do bardzo wąskiej kategorii spraw, w których orzeczenie naruszyło słuszne interesy jednostek, a ewentualna korekta orzeczenia nie doprowadzi do naruszenia praw innych osób. Konieczne wydaje się także doprecyzowanie przesłanek wniesienia skargi, które, jak zostało wykazane, mają charakter nieprecyzyjny, ocenny. Terminy o tak szerokim i ocennym zakresie znaczeniowym nie będą służyły faktycznej ochronie praw i wolności człowieka i obywatela, tym samym skarga nadzwyczajna nie spełni swej funkcji.

\section{BIBLIOGRAFIA}

\section{LITERATURA}

Adamczewski, Roman K. 2018. „Rażące naruszenie prawa w orzecznictwie sądów administracyjnych". Rzeczpospolita 13.03: 3.

Bagińska, Lidia. 2018. Skarga kasacyjna i nadzwyczajna w postępowaniu cywilnym. Komentarz praktyczny z orzecznictwem. Wzory pism procesowych i kazus. Warszawa: Wydawnictwo C.H. Beck.

Balcerzak, Michał. 2018. „Skarga nadzwyczajna do sądu najwyższego w kontekście skargi do europejskiego trybunału praw człowieka”. Palestra 1-2: 11-23.

Chmaj, Marek (red.). 2016. Wolności i prawa człowieka w konstytucji Rzeczypospolitej Polskiej. Warszawa: Wolters Kluwer Polska.

Domańska, Aldona. 2001. Zasady sprawiedliwości społecznej we współczesnym polskim prawie konstytucyjnym. Łódź: Wydawnictwo Uniwersytetu Łódzkiego.

Domańska, Aldona. 2020. „Zasady ustroju Rzeczypospolitej Polskiej”. W Dariusz Górecki (red.). Polskie prawo konstytucyjne. 63-85. Warszawa: Wolters Kluwer.

Działocha, Kazimierz. 1997. „Hierarchia norm konstytucyjnych i jej rola w rozstrzyganiu kolizji norm”. W Janusz Trzciński (red.). Charakter i struktura norm konstytucyjnych. 78-94. Warszawa: Wydawnictwo Sejmowe.

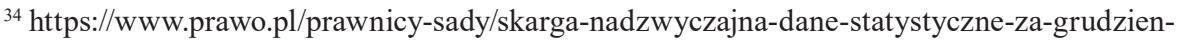
2019-r,496829.html [dostęp: 20.09.2020].

${ }^{35} \mathrm{https} / /$ www.batory.org.pl/upload/files/Programy\%20operacyjne/Forum\%20Idei/Sad\%20 Najwyzszy.pdf [dostęp: 20.09.2020]. 
Ereciński, Tadeusz. 2016. „Uwaga nr 15 do art. 3983 Kodeksu postępowania cywilnego”. W Tadeusz Ereciński (red.). Kodeks postępowania cywilnego. Komentarz. T. III. Postępowanie rozpoznawcze. LEX/el.

Ereciński, Tadeusz, Weitz, Karol. 2019, „Skarga nadzwyczajna w sprawach cywilnych”. Przegląd Sadowy 2: 7-20.

Opinia do przedtożonego przez Prezydenta Rzeczypospolitej Polskiej projektu ustawy o Sadzie Najwyższym, Warszawa, dnia 6 października 2017, s. 4, druk sejmowy nr 2003.

Opinia Ośrodka Badań, Studiów i Legislacji Krajowej Rady Radców Prawnych w przedmiocie skargi nadzwyczajnej przewidzianej w prezydenckim projekcie ustawy o Sądzie Najwyższym, Ośrodek Badań, Studiów i Legislacji Krajowej Rady Radców Prawnych, Warszawa, 12 listopada 2017 r.

Opinia prawna w sprawie konstytucyjności prezydenckiego projektu ustawy o Sądzie Najwyższym opinia zewnętrzna sporzadzona przez dr. hab. Marcina Matczaka, UW, druk sejmowy nr 2003.

Piasecki, Kazimierz (red.). 2016. Kodeks postępowania cywilnego. Komentarz. T. II. 2016 r., Komentarz do art. 3983 k.p.c. SIP Legalis.

Szczucki, Krzysztof. 2018. Ustawa o Sadzie Najwyższym. Komentarz. Warszawa: Wolter Kuwer Polska.

Tokarczyk, Roman A. 1997. „Sprawiedliwość jako naczelna wartość prawa”. Państwo i Prawo 6: 3-20.

Uzasadnienie projektu ustawy z 8 grudnia 2017 r. o Sądzie Najwyższym, druk sejmowy VIII kadencji nr 2003.

Wróblewski, Jerzy. 1990. „Z zagadnień pojęcia i ideologii państwa prawnego (analiza teoretyczna)”. Państwo i Prawo 6: 3-16.

\section{AKTY PRAWNE}

Konstytucja Rzeczypospolitej Polskiej z dnia 2 kwietnia 1997 r., Dz. U. z 1997 r., nr 78, poz. $483 \mathrm{ze} \mathrm{zm}$.

Ustawa z dnia 5 stycznia 2011 r. Kodeks wyborczy, t.j. Dz. U. z 2020 r., poz. 1319.

Ustawa z dnia 8 grudnia 2017 r. o Sądzie Najwyższym, t.j. Dz. U. z 2019 r., poz. 825; z 2020 r., poz. 190.

\section{ORZECZNICTWO}

Orzeczenie Trybunału Konstytucyjnego z 22 sierpnia1990 r., K 7/90.

Orzeczenie Trybunału Konstytucyjnego z 4 grudnia 1990 r., K 12/90.

Orzeczenie Trybunału Konstytucyjnego z 23 czerwca 1997 r., sygn. akt k 3/97.

Wyrok Trybunału Konstytucyjnego z 19 lutego 2003 r, sygn. akt P 11/02, OTK ZU nr 2/A/2003, poz. 12.

Wyrok Trybunału Konstytucyjnego z 17 maja 2004 r., sygn. akt SK 32/03.

Wyrok Trybunału Konstytucyjnego z 24 października 2007 r., sygn. akt SK 7/06.

Wyrok Trybunału Konstytucyjnego z 21 lipca 2009 r., sygn. akt K 7/09.

Postanowienie Trybunału Konstytucyjnego z 12 marca 2003 r., sygn. akt S 1/03.

Wyrok Sądu Najwyższego z 19 stycznia 1998 r., I CKN 424/97.

Wyrok Sądu Najwyższego z 8 marca 2012 r., III PK 52/11.

Wyrok Sądu Najwyższego z 3 czerwca 2019 r., I NSNc 7/19.

Postanowienie Sądu Najwyższego z 20 czerwca 1997 r., II CKN 246/97.

Postanowienie Sądu Najwyższego z 20 listopada 2002 r., II CKN 1492/00.

Postanowienie Sądu Najwyższego z 13 czerwca 2008 r., III CSK 104/08.

Postanowienie Sądu Najwyższego z 24 lipca 2019 r., I NSNc 5/19. 


\section{STRONY INTERNETOWE}

http://orka.sejm.gov.pl/Druki8ka.nsf/0/5AB89A44A6408C3CC12581D800339FED/\%24File/2003. pdf

https://www.batory.org.pl/upload/files/Programy\%20operacyjne/Forum\%20Idei/Sad\%20Najwyzszy. pdf

https://www.prawo.pl/prawnicy-sady/skarga-nadzwyczajna-dane-statystyczne-za-grudzien2019-r,496829.html

https://www.rp.pl/Sedziowie-i-sady/302059932-Tysiace-wnioskow-ale-malo-skarg-nadzwyczajnychdo-Sadu-Najwyzszego.html

https://www.rpo.gov.pl/pl/content/rpo-skarga-nadzwyczajna-ograniczyla-skargi-na-niezgodnosc-zprawem-prawomocnego-orzeczenia 